\title{
The impact of self-construal and ethnicity on self-gifting behaviors
}

DOI:

10.1016/j.jcps.2016.02.001

Document Version

Accepted author manuscript

Link to publication record in Manchester Research Explorer

\section{Citation for published version (APA):}

Pusaksrikit, T., \& Kang, J. (2016). The impact of self-construal and ethnicity on self-gifting behaviors. Journal of Consumer Psychology . https://doi.org/10.1016/j.jcps.2016.02.001

\section{Published in:}

Journal of Consumer Psychology

\section{Citing this paper}

Please note that where the full-text provided on Manchester Research Explorer is the Author Accepted Manuscript or Proof version this may differ from the final Published version. If citing, it is advised that you check and use the publisher's definitive version.

\section{General rights}

Copyright and moral rights for the publications made accessible in the Research Explorer are retained by the authors and/or other copyright owners and it is a condition of accessing publications that users recognise and abide by the legal requirements associated with these rights.

\section{Takedown policy}

If you believe that this document breaches copyright please refer to the University of Manchester's Takedown Procedures [http://man.ac.uk/04Y6Bo] or contact uml.scholarlycommunications@manchester.ac.uk providing relevant details, so we can investigate your claim.

\section{OPEN ACCESS}




\section{elsevier_JCPS_526}

Research Article

\section{The ilmpact of sSelf-cConstrual and eEthnicity on sSelf-gGifting bBehaviors}

Theeranuch Pusaksrikit ${ }^{a}$

theeranuch_pus@utcc.ac.th

Jikyeong Kang $\mathrm{b}^{\mathrm{b}, \mathrm{c}, *}$

jkang@aim.edu

aUniversity of the Thai Chamber of Commerce, 126/1 Vibhavadee-Rangsit Road, Dindaeng, Bangkok $k_{2}^{1} 10400$, Thailand

${ }^{\mathrm{b}}$ Asian Institute of Management, 123 Paseo de Roxas, 123 Paseo de Roxas, Makati 1229, Philippines

'Manchester Business School, Booth Street West, Booth Street West, Manchester M15 6PB, UK

${ }^{*}$ Corresponding author at: Asian Institute of Management, 123 Paseo de Roxas, Makati 1229, Philippines. Fax: + 6328924613.

\section{Abstract}

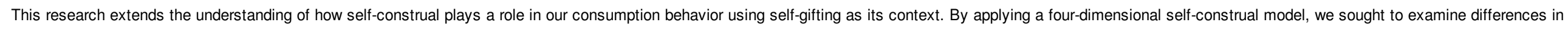

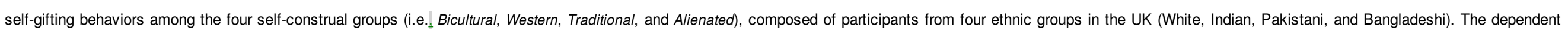

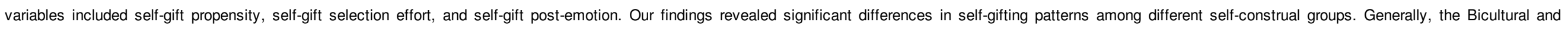

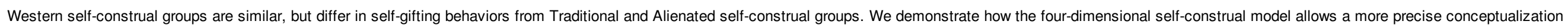
of self-construal and a more thorough investigation of cross-cultural consumption patterns than does the two-dimensional view.

Keywords: Bicultural; Independent self-construal; Interdependent self-construal; Self-gift

\section{Introduction}

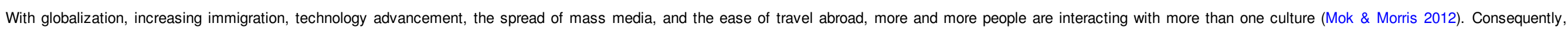

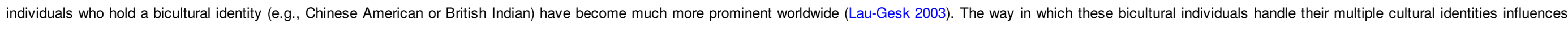

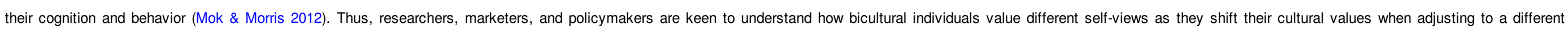
environment and being exposed to various new cultural contacts (Lu 2008; Yamada \& Singelis 1999).

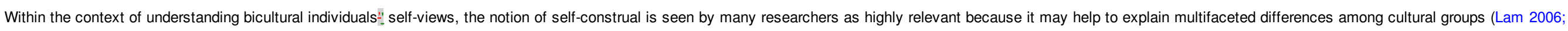

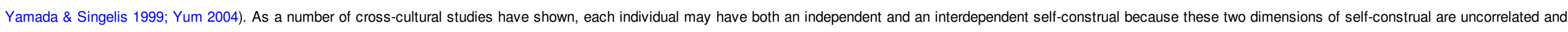

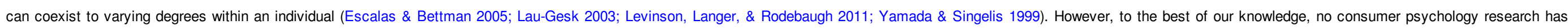

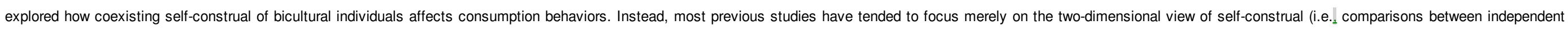
and interdependent self-construal individuals) (Matsumoto 1999).

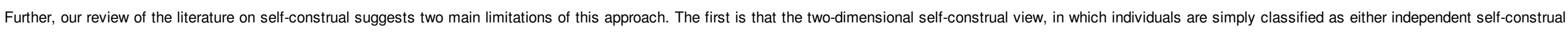

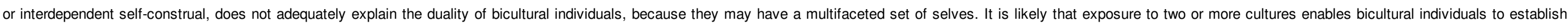

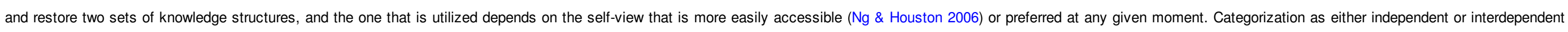




\section{elsevier_JCPS_526}

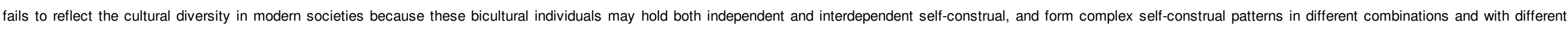
strengths (Kolstad \& Horpestad 2009).

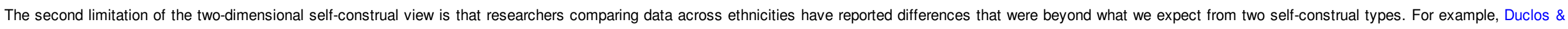

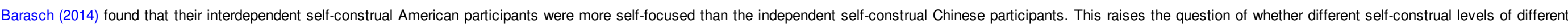

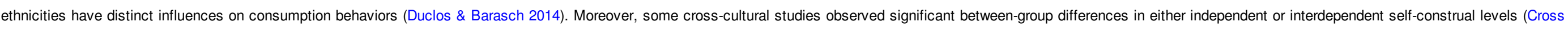

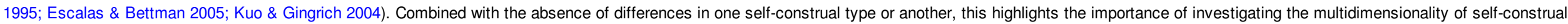

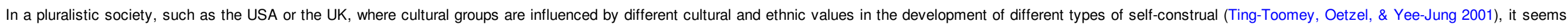

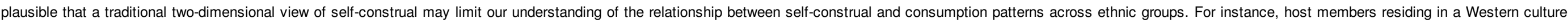

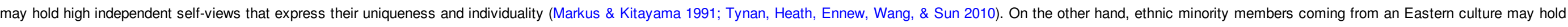
high interdependent self-views that place value on harmonious relationships with others (Markus \& Kitayama 1991; White, Lehman, \& Cohen 2006).

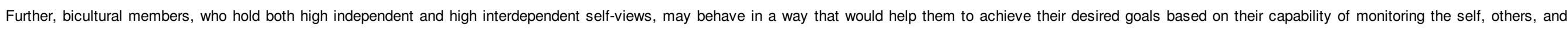

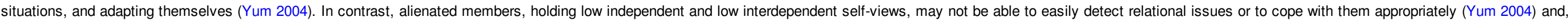

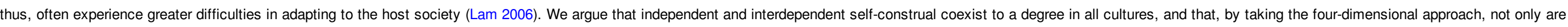
we able to extend our knowledge on self-construal but also could potentially explain unique consequences of self-construal on attitudes and behaviors (Kolstad \& Horpestad 2009).

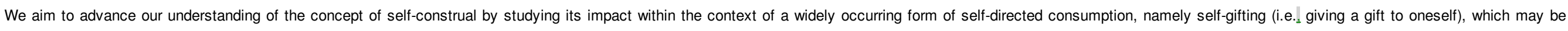

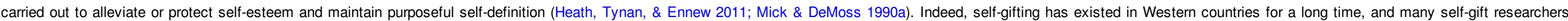

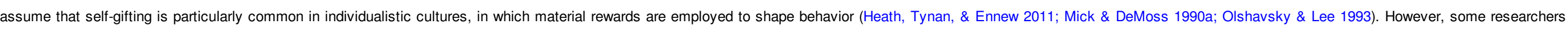

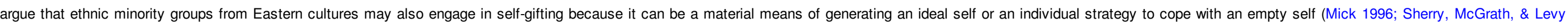
1995; Tynan, Heath, Ennew, Wang, \& Sun 2010).

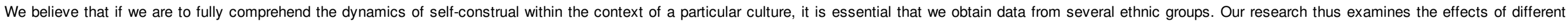
types of self-construal on self-gifting behaviors by comparing British White host members and Indian, Pakistani, and Bangladeshi ethnic minority members residing in the UK.

\section{Ttheoretical background}

\section{Self-construal}

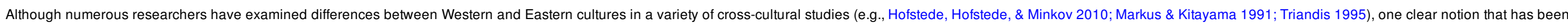

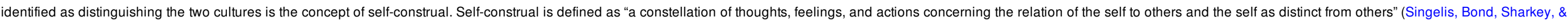
Lai 1999, p. 316) and is generally categorized into independent self-construal or interdependent self-construal (Markus \& Kitayama 1991).

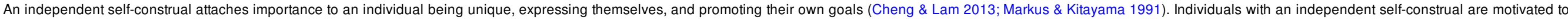

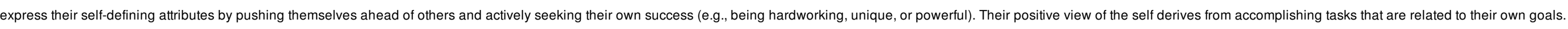

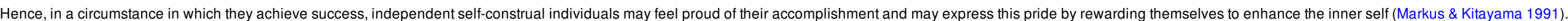

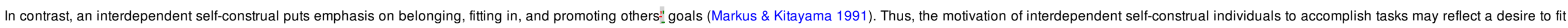

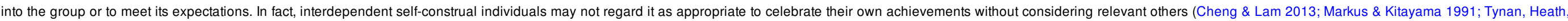

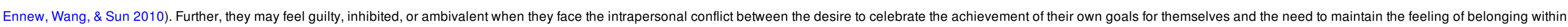
their group by engaging with relevant others (Markus \& Kitayama 1991; Joy, Hui, Chan, \& Cui 2006).

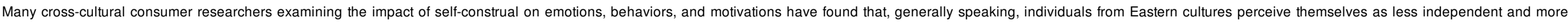




\section{elsevier_JCPS_526}

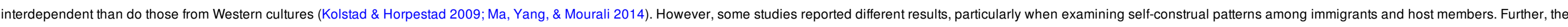

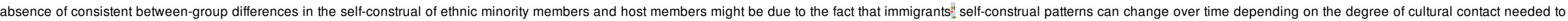

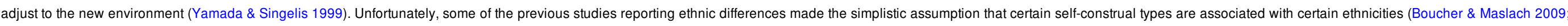
Matsumoto 1999). Hence, we feel that there is a strong need for a more robust treatment of the self-construal construct.

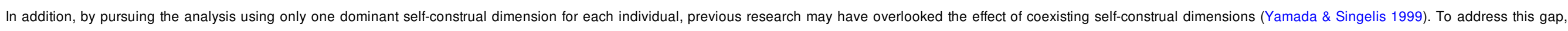

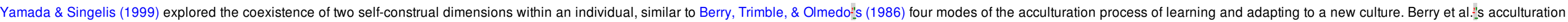

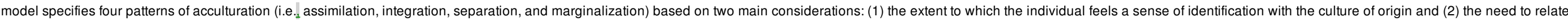

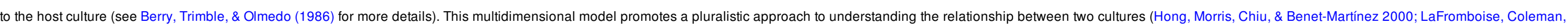
\& Gerton 1993).

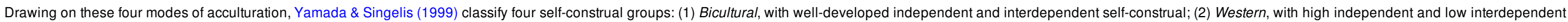
self-construal; (3) Traditional, with low independent and high interdependent self-construal; and (4) Alienated, with poorly developed independent and interdependent self-construal (see Figure. 1).

\begin{tabular}{|c|c|c|c|}
\hline \multicolumn{2}{|c|}{} & \multicolumn{2}{c|}{ Independent Self-Construal } \\
\cline { 2 - 4 } & High & Low \\
\hline \multirow{3}{*}{$\begin{array}{c}\text { Interdependent } \\
\text { Self-Construal }\end{array}$} & High & $\begin{array}{c}\text { Bicultural } \\
\text { Self-Construal Group }\end{array}$ & $\begin{array}{c}\text { Traditional } \\
\text { Self-Construal Group }\end{array}$ \\
\cline { 2 - 4 } & Low & $\begin{array}{c}\text { Western } \\
\text { Self-Construal Group }\end{array}$ & $\begin{array}{c}\text { Alienated } \\
\text { Self-Construal Group }\end{array}$ \\
\hline
\end{tabular}

Fig 1.Fig. 1 Yamada \& Singelis (1999) Four-dimensional self-construal model_.

alt-text: Fig. 1

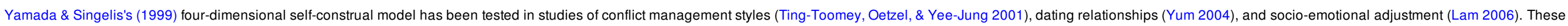

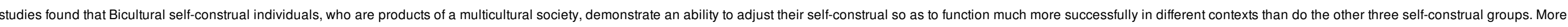

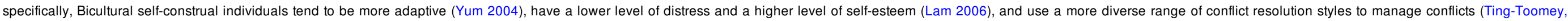

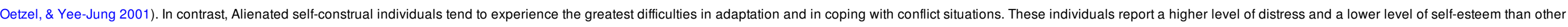
self-construal individuals. Western and Traditional self-construal individuals tend to develop strategies that are associated with their highly independent or highly interdependent self-construal, respectively.

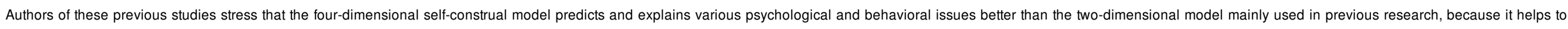

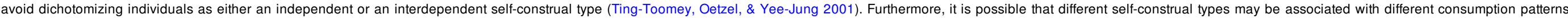

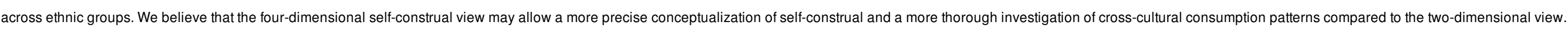

\section{Self-gifting}

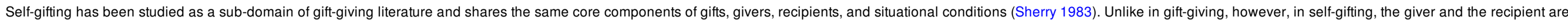
the same person.

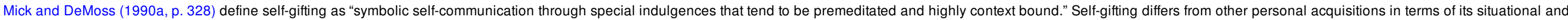

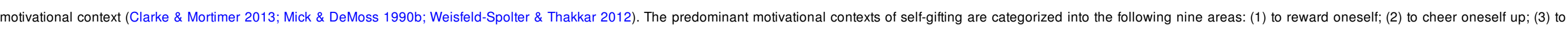

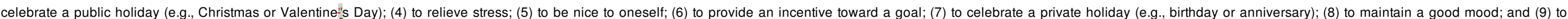
celebrate and spend extra money that has been earned or obtained (Mick \& DeMoss 1990b; McKeage, Richins, \& Debevec 1993). 


\section{elsevier_JCPS_526}

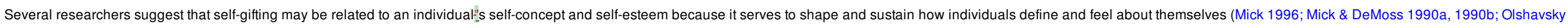

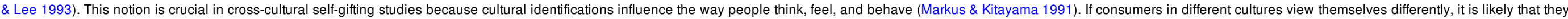

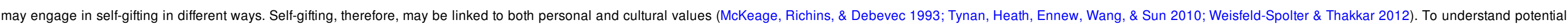

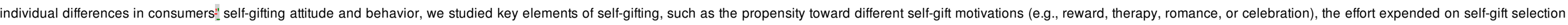
(e.g., time or money), and the emotional outcomes after self-gifting (e.g., feeling good or bad).

\section{Self-gift propensity}

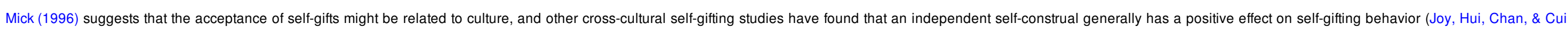

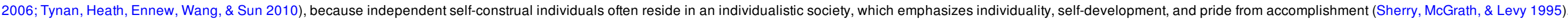

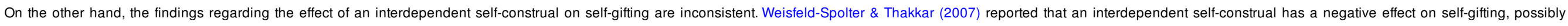

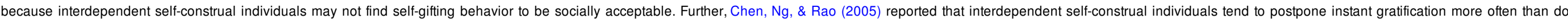

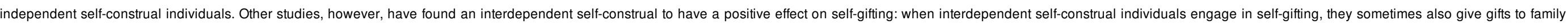
members in gratitude for their support (Joy, Hui, Chan, \& Cui 2006; Tynan, Heath, Ennew, Wang, \& Sun 2010).

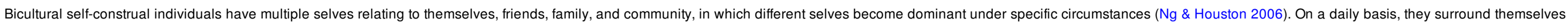

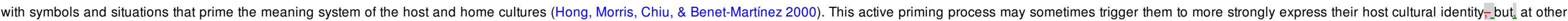
times $\mathbb{1}_{\perp}$ it may encourage them to maintain their home cultural identity (Hong, Morris, Chiu, \& Benet-Martínez 2000).

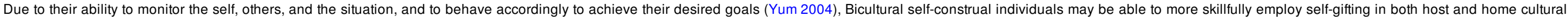

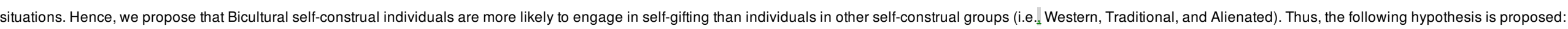

H1 Bicultural self-construal individuals have a higher level of self-gift propensity than Western, Traditional, and Alienated self-construal individuals

\section{Self-gift selection effort}

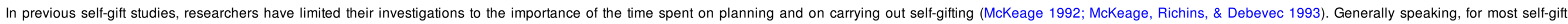

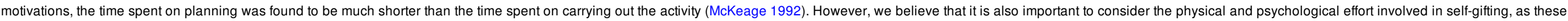
elements account for the distinctions between self-gifting and purchasing for everyday personal use.

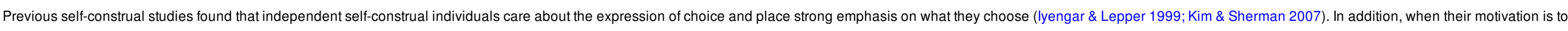

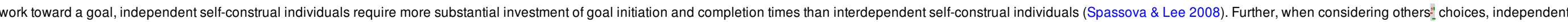

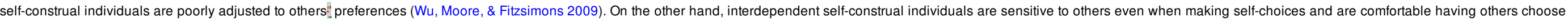
for them (Pöhlmann, Carranza, Hannover, \& lyengar 2007). Thus, they may not exert much effort when making their self-gifting decision.

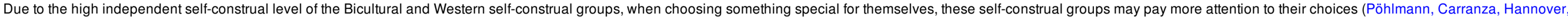

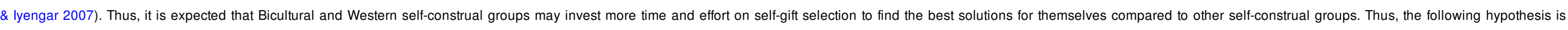
proposed:

H2 Bicultural and Western self-construal individuals expend more effort on self-gitt selection than Traditional and Alienated self-construal individuals.

\section{Post-emotion of self-gifting}

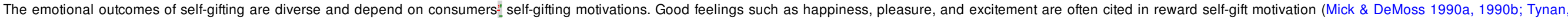

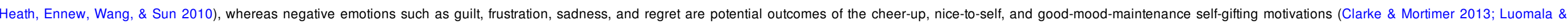




\section{elsevier_JCPS_526}

Laaksonen 1999). Further, self-gifting sometimes produces mixed emotions that combine satisfaction and guilt, due to the struggle and negotiation between desiring and deserving (Sherry, McGrath, \& Levy 1995).

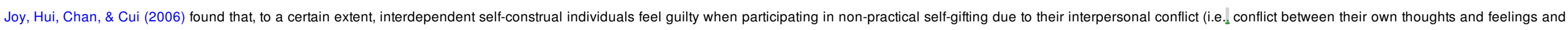

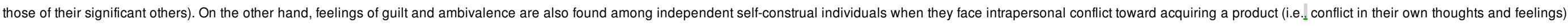
(Park, Priester, Petty, Lee, \& Wang 2002).

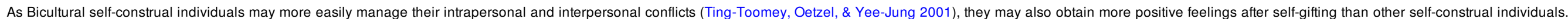
Thus, the following hypothesis is proposed:

H3 Bicultural self-construal individuals experience more positive post-emotion of self-gifting than Western, Traditional, and Alienated self-construal individuals.

\section{METHODSethods}

\section{Overview and research design}

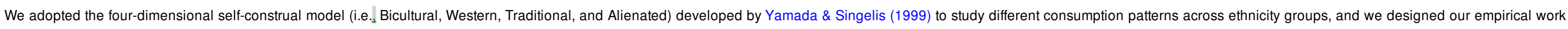
within the context of self-gifting among four ethnicity groups (i.e.] British Indians, British Pakistanis, British Bangladeshis, and British Whites) in the UK.

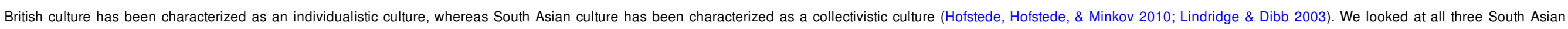

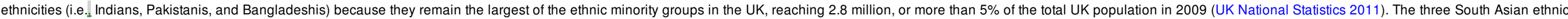

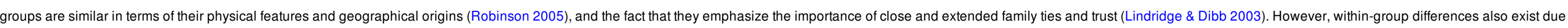
to the differences in South Asian ethnic groups:- nationalities, linguistic traditions, religions, migration histories, and processes of adjustment into the host society (Ghuman 1997; Lindridge 2010).

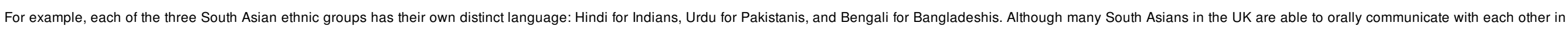

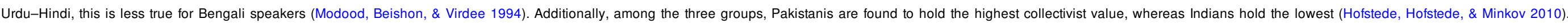

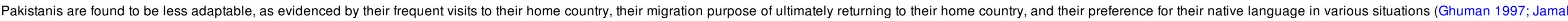

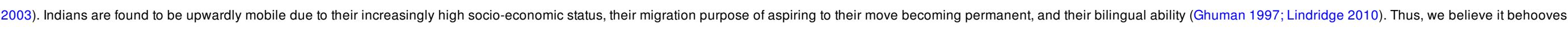
us to explore differences in self-gifting at a subcultural group level (i.e.] Indians, Pakistanis, and Bangladeshis).

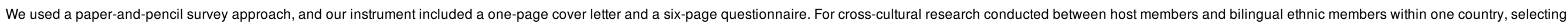

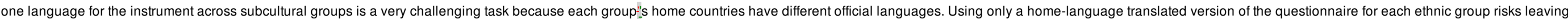

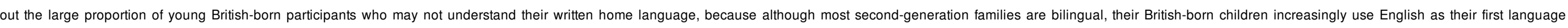

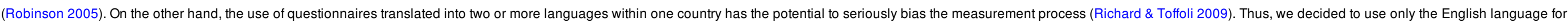
the instrument, so as not to compromise its equivalence and validity, and to minimize the response bias.

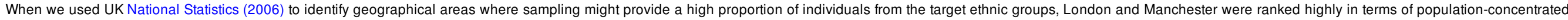

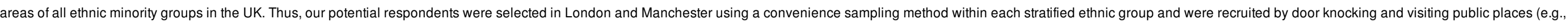
shops, supermarkets, restaurants, parks, religious places, travel agencies, schools, universities, and community organizations).

\section{Measurements}

\section{Self-construal}

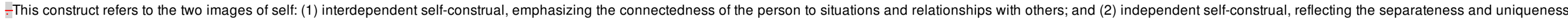

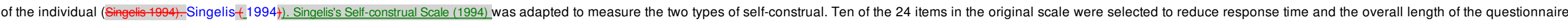

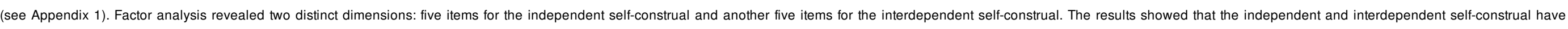




\section{elsevier_JCPS_526}

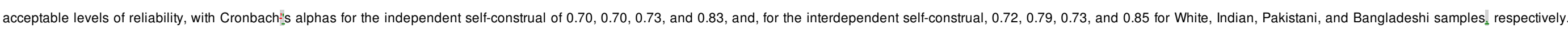

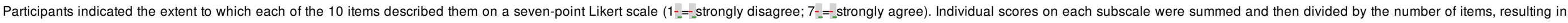
scores for each subscale ranging from 1 to 7 .

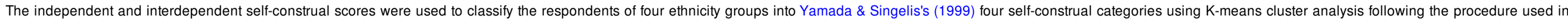

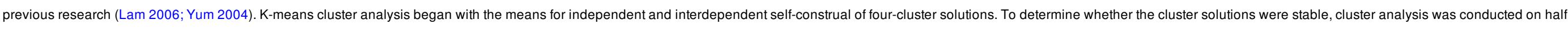
of the sample, and the means from the clusters of the first half were used as the starting points for cluster solutions using the other half of the sample.

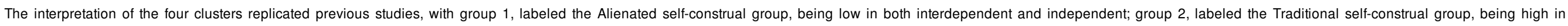

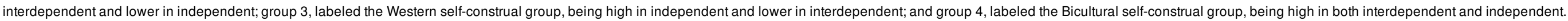

\section{Self-gift propensity.}

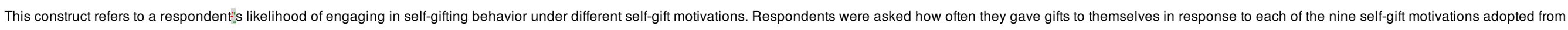

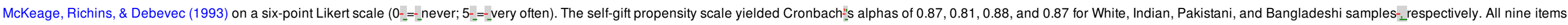
were summed and divided by the number of items to compute a composite score of self-gift propensity for each respondent.

\section{Self-gift selection effort.}

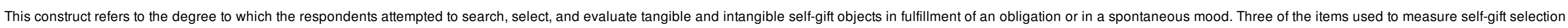

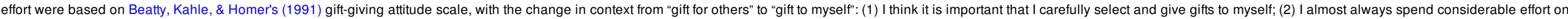

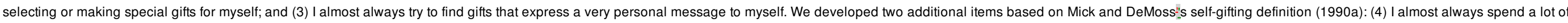

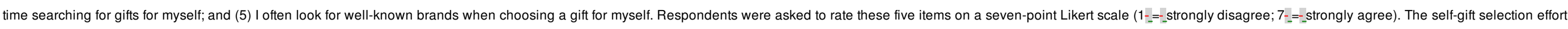

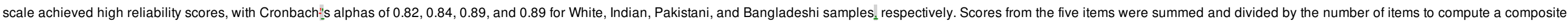
score of self-gift selection effort.

\section{Post-emotion of self-gifting.}

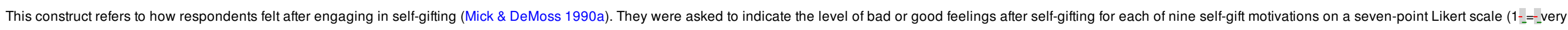

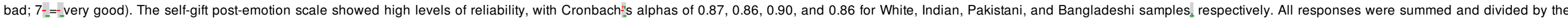
number of items that received responses.

\section{The sample}

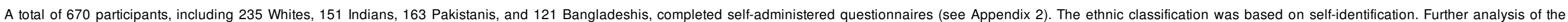

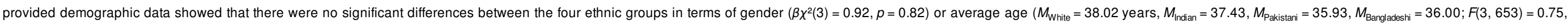
$p=0.52)$. However, we found significant differences among the ethnic groups in terms of educational level $\left(\chi^{2}(9)=23.25, p<0.01\right)$, employment status $\left(\chi^{2}(12)=43.47, p<0.001\right)$, and personal income level $\left(\chi^{2}(9)=20.80, p<0.05\right)$.

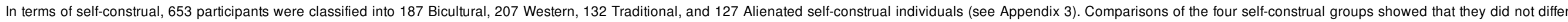

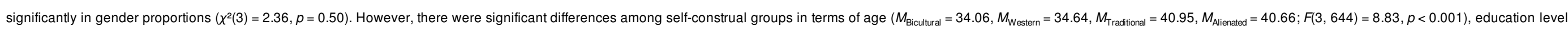
$\left(\chi^{2}(9)=30.26, p<0.001\right)$, employment status $\left(\chi^{2}(12)=35.16, p<0.001\right)$, personal income level $\left(\chi^{2}(9)=17.42, p<0.05\right)$, and ethnicity $\left(\chi^{2}(9)=46.91, p<0.001\right)$.

\section{Statistical analyses}

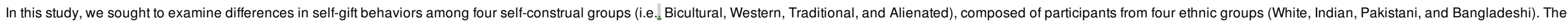
dependent variables were individual respondents"] mean scores of self-gift propensity, self-gift selection effort, and self-gift post-emotion. 


\section{elsevier_JCPS_526}

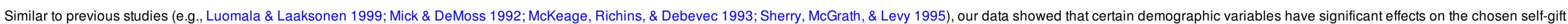

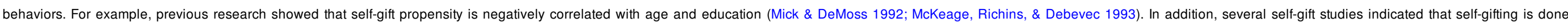

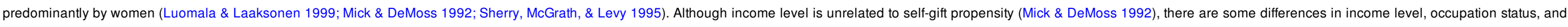

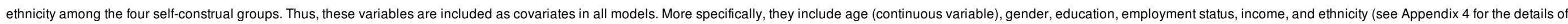
dummy coding for categorical variables).

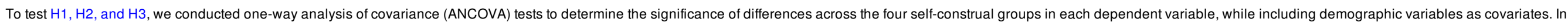

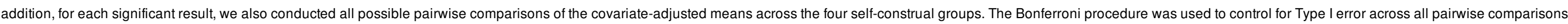

\section{ResultsESULTS}

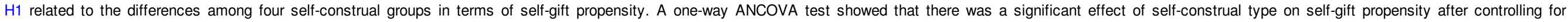

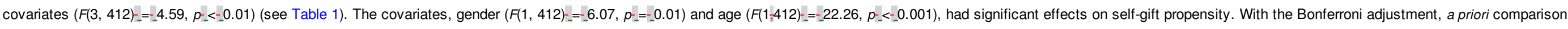

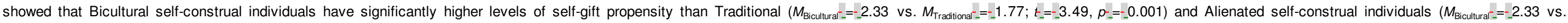

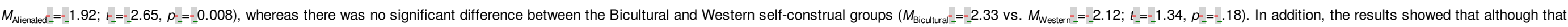

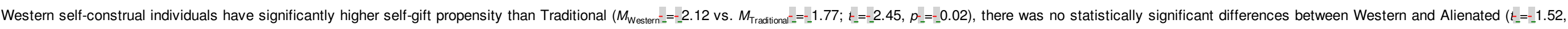
$p_{-}=-13$ ), and Traditional and Alienated self-construal groups $\left(t_{-}=-.94, p_{-}=-.35\right)$ (see Table 2). Thus, $\mathrm{H} 1$ is partially supported.

Fable 1.Table 1 One-way analysis of covariance: self-gift propensity

alt-text: Table 1

\begin{tabular}{|c|c|c|c|}
\hline Source & $d f$ & MS & $F$ \\
\hline Gender & 1 & 6.25 & $6.07^{*}$ \\
\hline Age & 1 & 23.07 & $22.26^{\star \star \star}$ \\
\hline \multicolumn{4}{|l|}{ Education } \\
\hline -A level & 1 & 0.33 & 0.32 \\
\hline -First degree & 1 & 1.55 & 1.50 \\
\hline - Master's/doctoral degree & 1 & 0.98 & 0.95 \\
\hline \multicolumn{4}{|l|}{ Employment status } \\
\hline -Full-time student & 1 & 0.01 & 0.01 \\
\hline -Full-time employment & 1 & 1.27 & 1.23 \\
\hline -Part-time paid work & 1 & 0.63 & 0.61 \\
\hline -Retired from work & 1 & 1.80 & 1.74 \\
\hline \multicolumn{4}{|l|}{ Annual income } \\
\hline$-£ 20,000-29,999$ & 1 & 1.61 & 1.55 \\
\hline$-£ 30,000$ or more & 1 & 1.31 & 1.27 \\
\hline
\end{tabular}

Ethnicity 


\section{elsevier_JCPS_526}

\begin{tabular}{|l|l|}
\hline -_ndian & 1 \\
\hline -Pakistani & 1 \\
\hline -Bangladeshi & 1 \\
\hline Self-construal & 3 \\
\hline Error & 412 \\
\hline Total & 431
\end{tabular}

\begin{tabular}{|l|l|}
\hline 0.56 & 0.54 \\
\hline 0.96 & 0.92 \\
\hline 0.83 & 0.80 \\
\hline 4.75 & $4.59^{\star \star}$ \\
\hline 1.04 & \\
\hline & \\
\hline
\end{tabular}

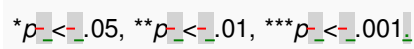

Fable 2:Table 2 Pairwise comparisons: self-gift propensity by self-construal groups.

\section{alt-text: Table 2}

\begin{tabular}{|c|c|c|c|c|c|c|c|}
\hline \multirow{2}{*}{$\begin{array}{l}\text { Self-construal_ } \\
\text { groups }\end{array}$} & \multirow[b]{2}{*}{$N$} & \multirow[t]{2}{*}{ Adjusted mean } & \multirow[b]{2}{*}{ SE } & \multicolumn{4}{|c|}{ Adjusted mean differences } \\
\hline & & & & Bicultural & Western & Traditional & Alienated \\
\hline Bicultural & 125 & 2.33 & 0.09 & - & & & \\
\hline Western & 141 & 2.12 & 0.09 & 0.21 & - & & \\
\hline Traditional & 78 & 1.77 & 0.12 & $0.56^{* \star *}$ & $-0.35^{\star}$ & - & \\
\hline Alienated & 87 & 1.92 & 0.11 & $0.41^{* *}$ & -0.20 & $=0.15$ & - \\
\hline
\end{tabular}

${ }^{*} p_{-}<-.05,{ }^{* *} p_{-}<-<.01,{ }^{* * *} p_{-}<-.001$.

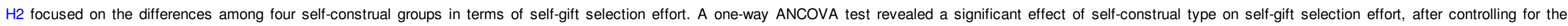

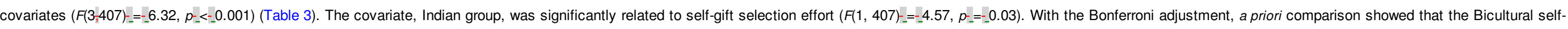

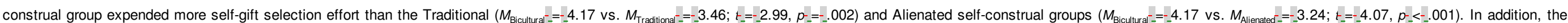

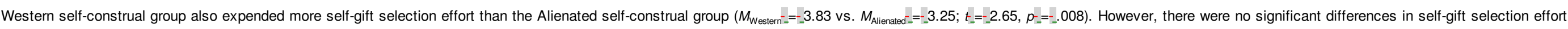
between Bicultural and Western $\left(t_{-}=-1.71, p_{-}=-.09\right)$, Western and Traditional $\left(t_{-}=-1.61, p_{-}=-11\right)$, and Traditional and Alienated self-construal groups $\left(t_{-}=-0.83, p_{-}=-.41\right)($ see Table 4$)$. Thus, $\mathrm{H}_{2}$ is partially supported.

Fable 3-Table 3 One-way analysis of covariance: self-gift selection effort.

alt-text: Table 3

Source

MS

\begin{tabular}{|c|c|c|c|}
\hline Gender & 1 & 0.16 & 0.07 \\
\hline Age & 1 & 1.14 & 0.47 \\
\hline \multicolumn{4}{|l|}{ Education } \\
\hline -A level & 1 & 4.38 & 1.79 \\
\hline -First degree & 1 & 3.39 & 1.39 \\
\hline - Master's/doctoral degree & 1 & 1.66 & 0.68 \\
\hline
\end{tabular}




\section{elsevier_JCPS_526}

\begin{tabular}{|c|c|c|c|}
\hline -Full-time student & 1 & 3.33 & 1.36 \\
\hline -Full-time employment & 1 & 0.56 & 0.23 \\
\hline -Part-time paid work & 1 & 3.57 & 1.46 \\
\hline -Retired from work & 1 & 0.21 & 0.09 \\
\hline \multicolumn{4}{|l|}{ Annual income } \\
\hline$-£ 10,000-19,999$ & 1 & 0.23 & 0.10 \\
\hline$-£ 20,000-29,999$ & 1 & 0.44 & 0.18 \\
\hline$-£ 30,000$ or more & 1 & 3.83 & 1.56 \\
\hline \multicolumn{4}{|l|}{ Ethnicity } \\
\hline -Indian & 1 & 11.18 & $4.57^{*}$ \\
\hline -Pakistani & 1 & 5.19 & 2.12 \\
\hline -Bangladeshi & 1 & 5.27 & 2.16 \\
\hline Self-construal & 3 & 15.45 & $-6.32^{* * *}$ \\
\hline Error & 407 & 2.45 & \\
\hline Total & 426 & & \\
\hline
\end{tabular}

$\left.{ }^{*} p_{-}-<-\ldots 05,{ }^{* * *} p p_{-}<-<.001\right]$

Fable 4-Table 4 Pairwise comparisons: self-gift selection effort by self-construal groups. alt-text: Table 4

\begin{tabular}{|c|c|c|c|c|c|c|c|}
\hline \multirow{2}{*}{$\begin{array}{l}\text { Self-construal } \\
\text { groups }\end{array}$} & \multirow[t]{2}{*}{$N$} & \multirow[t]{2}{*}{ Adjusted mean } & \multirow[t]{2}{*}{ SE } & \multicolumn{4}{|c|}{ Adjusted mean differences } \\
\hline & & & & Bicultural & Western & Traditional & Alienated \\
\hline Bicultural & 123 & 4.17 & 0.15 & - & & & \\
\hline Western & 140 & 3.83 & 0.14 & -0.34 & - & & \\
\hline Traditional & 77 & 3.46 & 0.19 & $0.72^{\star *}$ & 0.37 & - & \\
\hline Alienated & 86 & 3.25 & 0.17 & $0.93^{\star \star \star}$ & $-0.58^{\star *}$ & 0.21 & - \\
\hline
\end{tabular}

${ }^{* *} p-<<-.01,{ }^{* * *} p_{-}<.001$.

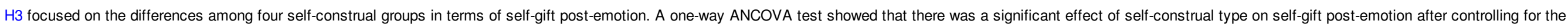

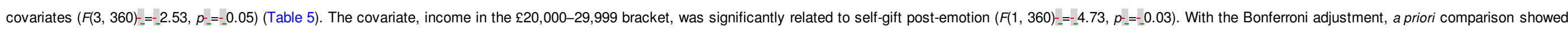

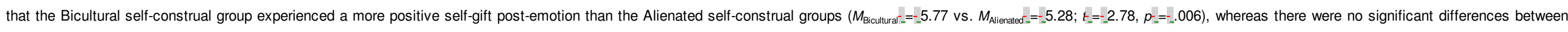

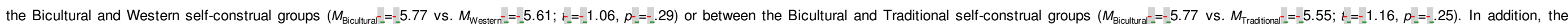

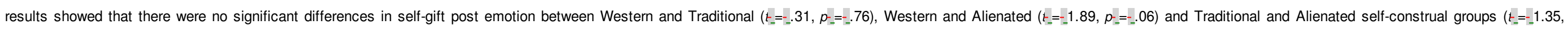
$p_{-}=-$. 18) (see Table 6). Thus, $\mathrm{H} 3$ is only marginally supported. 


\section{elsevier_JCPS_526}

Fable 5:Table 5 One-way analysis of covariance: post-emotion of self-gifting. alt-text: Table 5

\begin{tabular}{|c|c|c|c|}
\hline & $d f$ & MS & $F$ \\
\hline Gender & 1 & 2.27 & 1.63 \\
\hline Age & 1 & 1.89 & 1.36 \\
\hline \multicolumn{4}{|l|}{ Education } \\
\hline -A level & 1 & 4.63 & 3.33 \\
\hline -First degree & 1 & 2.09 & 1.51 \\
\hline -_Master's/doctoral degree & 1 & 0.15 & 0.11 \\
\hline \multicolumn{4}{|l|}{ Employment status } \\
\hline -Full-time student & 1 & 1.48 & 1.06 \\
\hline -Full-time employment & 1 & 0.45 & 0.33 \\
\hline -Part-time paid work & 1 & 0.48 & 0.34 \\
\hline -Retired from work & 1 & 0.94 & 0.68 \\
\hline \multicolumn{4}{|l|}{ Annual income } \\
\hline$-£ 10,000-19,999$ & 1 & 0.19 & 0.13 \\
\hline$-£ 20,000-29,999$ & 1 & 6.58 & $4.73^{\star}$ \\
\hline - £30,000 or more & 1 & 4.74 & 3.41 \\
\hline \multicolumn{4}{|l|}{ Ethnicity } \\
\hline -Indian & 1 & 0.12 & 0.08 \\
\hline -Pakistani & 1 & 1.24 & 0.89 \\
\hline -Bangladeshi & 1 & 2.14 & 1.54 \\
\hline Self-construal & 3 & 3.51 & $2.53^{*}$ \\
\hline Error & 364 & 1.39 & \\
\hline Total & 383 & & \\
\hline
\end{tabular}

$* p-<.05$

Fable 6:Table 6 Pairwise comparisons: post-emotion of self-gifting by self-construal groups,

alt-text: Table 6

Self-Construal Groups

Adjusted mean

Adjusted mean differences

\begin{tabular}{|l|l|l|}
\hline Bicultural & \multicolumn{2}{|c|}{ N } \\
\hline Western & 118 & 5.77 \\
\hline
\end{tabular}

\begin{tabular}{|l|l|}
\multicolumn{1}{|c|}{ SE } & \\
\hline .11 & - \\
\hline .10 & 0.16
\end{tabular}

Bicultural

Western

Traditional

Alienated 


\begin{tabular}{|c|c|c|c|c|c|c|c|}
\hline Traditional & 64 & 5.55 & .15 & 0.22 & 0.06 & - & \\
\hline Alienated & 74 & 5.28 & .14 & $0.49^{\star \star}$ & 0.33 & 0.27 & - \\
\hline
\end{tabular}

$* * p<.01$.

\section{DiscussioniscussION}

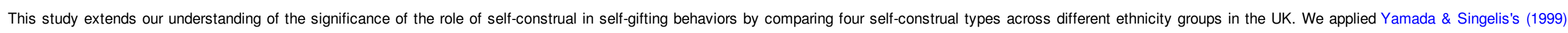

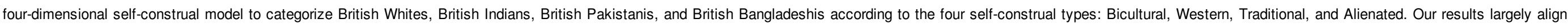

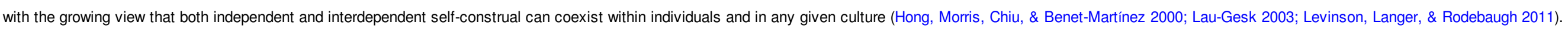

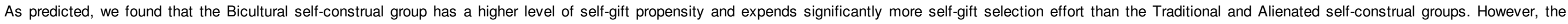

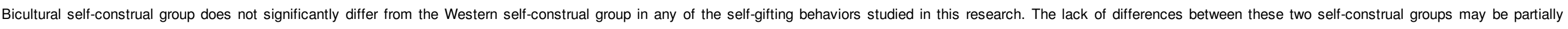
attributed to the stronger impact of high independent self-construal level on self-gifting behaviors.

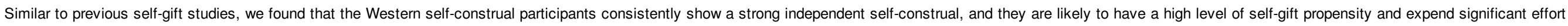

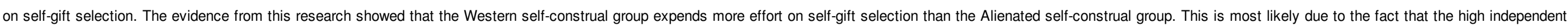

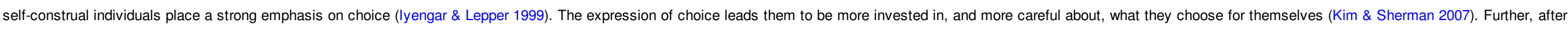

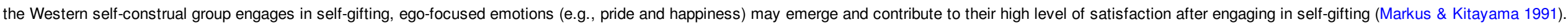

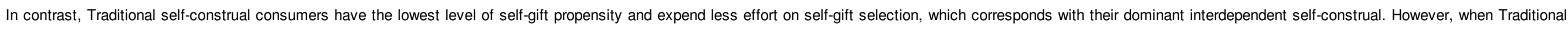
self-construal consumers engage in self-gifting, they have more positive emotional self-gift experiences.

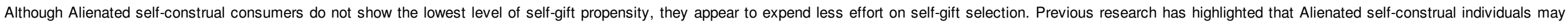

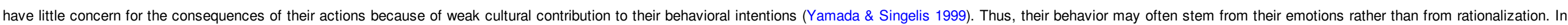

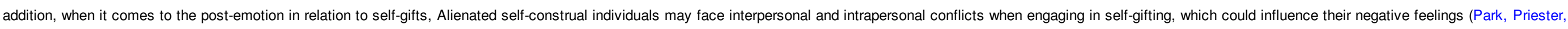
Petty, Lee, \& Wang 2002)

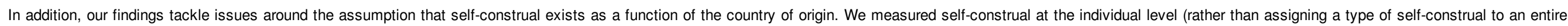

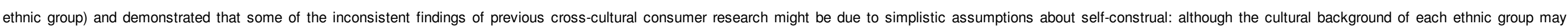
determine their chronic self-construal, people are capable of shifting their chronic type of self-construal in response to situational accessibility (Hong, Morris, Chiu, \& Benet-Martínez 2000; White, Lehman, \& Cohen 2006).

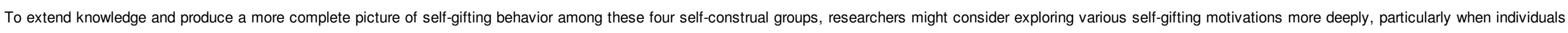

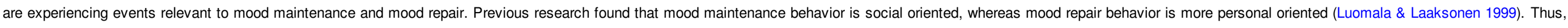
the self-gifting behavior of interdependent self-construal individuals, who value the group"s feelings over their own, may differ from that of independent self-construal individuals.

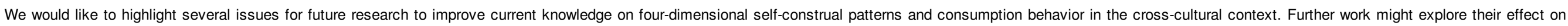

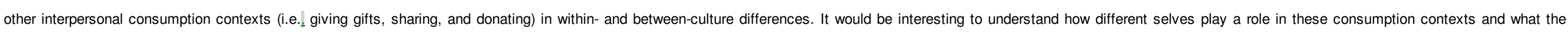

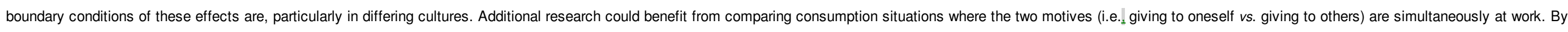

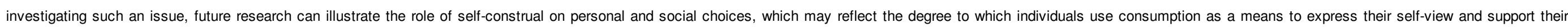
community.

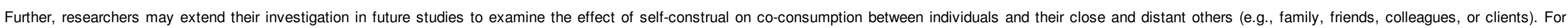

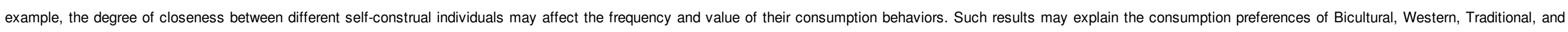




\section{elsevier_JCPS_526}

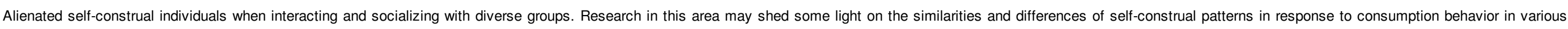
cultures and situations.

\section{Uncited reference}

National Statistics, 2006

\section{Appendix A.Appendix A. Supplementary data}

Supplementary data to this article can be found online at http://dx.doi.org/10.1016/j.jcps.2016.02.001.

\section{References}

Beatty S.E.S.E., Kahle L.P.L.R. and Homer P., Personal values and gift-giving behaviors: A study across cultures, Journal of Business Research 22 (2), 1991, 149-157.

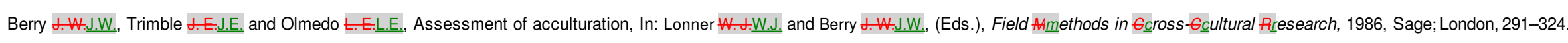

Boucher H.G.H.C. and Maslach C., Culture and tindividuation: The role of norms and self-construals, The Journal of Social Psychology 149 (6), $2009,677-693$.

Chen H., Ng S. and Rao A.R.A.R., Cultural differences in consumer impatience, Journal of Marketing Research 42 (3), 2005, 291-301.

Cheng R.W.R.W. and Lam S., The interaction between social goals and self-construal on achievement motivation, Contemporary Educational Psychology 38 (2), 2013, 136-148.

Clarke P. D.P.D. and Mortimer G., Self-gifting guilt: An examination of self-gifting motivations and post-purchase regret, Journal of Consumer Marketing 30 (6), $2013,472-483$.

Cross S.E.S.E., Self-construal, coping, and stress in cross-cultural adaptation, Journal of Cross-Cultural Psychology 26 (6), 1995, 673-697.

Duclos R. and Barasch A., Prosocial behavior in intergroup relations: How donor self-construal and recipient group-membership share generosity, Journal of Consumer Research 41 (1), $2014,93-108$.

Escalas J.E.J.E. and Bettman J.R.J.R., Self-construal, reference groups, and brand meaning, Journal of Consumer Research 32 (3), 2005, 378-389.

Ghuman P.A. S.P.A.S., Assimilation or integration? A study of Asian adolescents, Educational Research 39 (1), 1997, $23-35$.

Heath A.T.M.T., Tynan C. and Ennew G.T.C.T., Self-gift giving: Understanding consumers and exploring brand messages, Journal of Marketing Communications 17 (2), 2011 , $127-144$.

Hofstede G.H.G.H., Hofstede G.J.G.J. and Minkov M., Cultures and organizations: Software of the mind, 3rdedition3rd ed., 2010, McGraw-Hill; Berkshire.

Hong Y., Morris M.W.M.W., Chiu G.Y.C.Y. and Benet-Martínez V., Multicultural minds: A dynamic constructivist approach to culture and cognition, American Psychologist 55 (7), $2000,709-720$.

lyengar S.S.S.S. and Lepper A.R.M.R., Rethinking the value of choice: A cultural perspective on intrinsic motivation, Journal of Personality and Social Psychology 76 (3), $1999,349-366$.

Jamal A., Marketing in a multicultural world: The interplay of marketing, ethnicity and consumption, European Journal of Marketing 37 (11/12), 2003, 1599-1620.

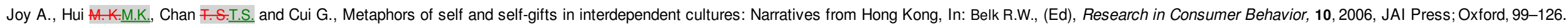

Kim H.S.H.S. and Sherman D.K.D.K., "Express ¥yourself”: Culture and the effect of self-expression on choice, Journal of Personality and Social Psychology 92 (1), $2007,1-15$.

Kolstad A. and Horpestad S., Self-construal in Chile and Norway: Implications for cultural differences in individualism and collectivism, Journal of Cross-Cultural Psychology 40 (2), $2009,275-281$.

Kuo B.G.B.C. and Gingrich L., Correlates of self-construal among Asian and Caucasian undergraduates in Canada: Cultural patterns and implications for counselling, Guidance and Counselling 20 (2), $2004,78-88$.

LaFromboise T., Coleman H. and Gerton J., Psychological impact of biculturalism, Psychological Bulletin 114 (3), 1993, 395-412.

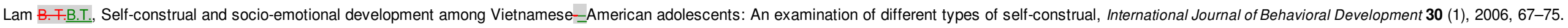




\section{elsevier_JCPS_526}

Lau-Gesk L., Activating culture through persuasion appeals: An examination of the bicultural consumer, Journal of Consumer Psychology 13 (3), 2003, 301-315.

Levinson C.A., Langer J.K.J.K. and Rodebaugh F.L.T.L., Social anxiety and self-construal: Considering personality, Personality and Individual Differences 51 (3), 2011 , 355-359.

Lindridge A., Are we fooling ourselves when we talk about ethnic homogeneity? The case of religion and ethnic sub-divisions amongst Indians living in Britain, Journal of Marketing Management 26 (5-6), $2010,441-472$.

Lindridge A. and Dibb S., Is 'culture' a justifiable variable for market segmentation? A cross-cultural example, Journal of Consumer Behaviour 2 (3), $2003,269-287$.

Lu L., The individual-oriented and social-oriented Chinese bicultural self: Testing the theory, Journal of Social Psychology 148 (3), 2008, 347-373.

Luomala H. T.H.T. and Laaksonen M., A qualitative exploration of mood-regulatory self-gift behaviors, Journal of Economic Psychology 20 (2), 1999, 147-182.

Ma Z., Yang Z. and Mourali M., Consumer adoption of new products: Independent versus interdependent self-perspectives, Journal of Marketing 78 (2), $2014,101-117$.

Markus H.R.H.R. and Kitayama S., Culture and the self: Implications for cognition, emotion, and motivation, Psychological Review 98 (2), 1991, 224-253.

Matsumoto D., Culture and self: An empirical assessment of Markus and Kitayama's theory of independent and interdependent self-construal, Asian Journal of Social Psychology 2 (3), 1999, 289-310.

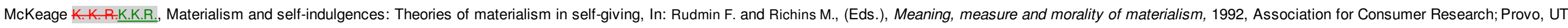
$140-146$.

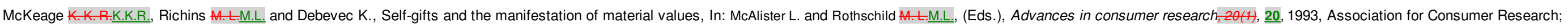
Provo, UT, 359-364, (1).

Mick D.G.D.G., Self-gifts, In: Otnes C. and Beltramini R., (Eds.), Gift giving: A research anthology, 1996, Bowling Green University Press; Bowling Green, OH, 99-120.

Mick D.G.D.G. and DeMoss M., Self-gifts: Phenomenological insights from four contexts, Journal of Consumer Research 17 (3), $1990 \mathrm{a}, 322-332$.

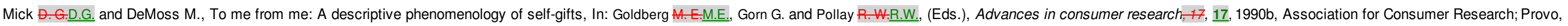
UT, 677-682.

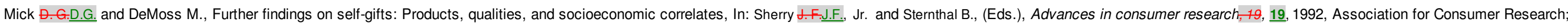
Provo, UT, 140-146.

Modood T., Beishon S. and Virdee S., Changing Eethnic tidentities, 1994, Policy Studies Institute; London.

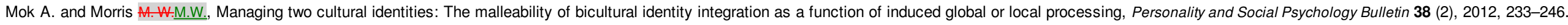

Ng S. and Houston M. J.M.J., Exemplars or beliefs? The impact of self-view on the nature and relative influence of brand associations, Journal of Consumer Research 32 (4), $2006,519-529$.

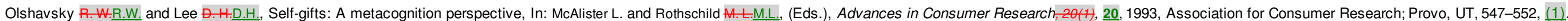

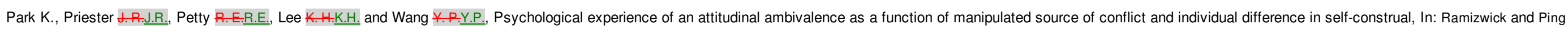

T., (Eds.), Asia Pacific Advances in Consumer Research,5, 5, 2002, Valdosta, GA; Association for Consumer Research, 287-289.

Pöhlmann C., Carranza E., Hannover B. and lyengar S. S.S.S., Repercussions of self-construal for self-relevant and other-relevant choice, Social Cognition 25 (2), $2007,284-305$.

Richard M. O.M.O. and Toffoli R., Language influence in responses to questionnaires by bilingual respondents: A test of the Whorfian hypothesis, Journal of Business Research 62 (10), 2009 , 987-1001.

Robinson L., South Asians in Britain: Acculturation, identity and perceived discrimination, Psychology and Developing Societies 17 (2), $2005,181-194$.

Sherry J., Jr., Gift giving in anthropological perspective, Journal of Consumer Research 10 (2), 1983, 157-168. 


\section{elsevier_JCPS_526}

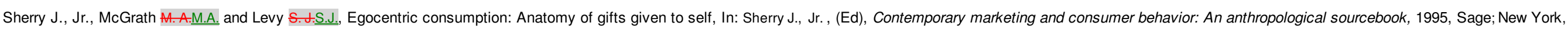
399-432.

Singelis T.M.T.M., The measurement of independent and interdependent self-construals, Personality and Social Psychology Bulletin 20 (5), $1994,580-591$.

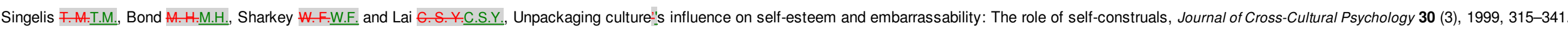

Spassova G. and Lee A.Y.A.Y., Self-construal and temporal distance, In: Lee A. Y.A.Y. and Soman D., (Eds.), Advances in consumer research,35, 35, 2008, Association for Consumer Research; Duluth, MN, 841-842.

Ting-Toomey S., Oetzel J. and Yee-Jung K., Self-construal types and conflict management styles, Communication Reports 14 (2), 2001, 87-104.

Triandis H.C.H.C., Individualism and Gcollectivism, 1995, Westview Press; San Francisco, California.

Tynan C., Heath M., Ennew C., Wang F. and Sun L., Self-gift giving in China and the UK: Collectivist versus individualist orientations, Journal of Marketing Management 26 (11-12), 2010, 1112-1128.

UK National Statistics, Geographic diversity, In: Dobbs J., Green H. and Zealey L., (Eds.), Focus on ethnicity and religion, 2006, Palgrave Macmillan; New York, 1-165, (2006).

UK National Statisties (2006). Geographie diversity. In J. Dobbs, H. Green, \& L. Zealey (Eds.), Foeus on ethnieity and religion: 2006 (pp.1-165). New York: Palgrave Maemillan.

UK National Statistics, Population estimates by ethnic group 2002-2009, In: Statistical bulletin, 2011, Office for National Statistics; England and Wales, 1-11.

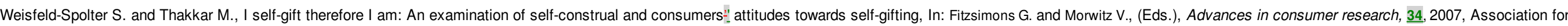

Consumer Research; Duluth, MN, 414-416

Weisfeld-Spolter S. and Thakkar M., A framework for examining the role of culture in individuals likelihood to engage in self-gift behavior, Academy of Marketing Studies Journal 16 (1), $2012,39-52$. White K., Lehman D.R.D.R. and Cohen D., Culture, self-construal, and affective reactions to successful and unsuccessful others, Journal of Experimental Social Psychology 42 (5), $2006,582-592$.

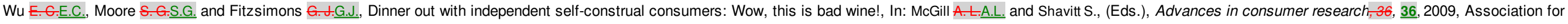
Consumer Research; Duluth, MN, 996.

Yamada A. M.A.M. and Singelis F. A.T.M., Biculturalism and self-construal, International Journal of Intercultural Relations 23 (5), 1999, 697-709.

Yum Y., Culture and self-construal as predictors of responses to accommodative dilemmas in dating relationships, Journal of Social and Personal Relationships 21 (6), $2004,817-835$.

\section{Appendix A.Appendix A. Supplementary data}

Multimedia Component 1

Supplementary material

alt-text: Image 1

\section{Queries and Answers}

Query:

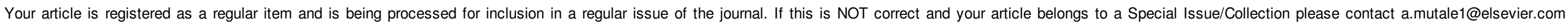
immediately prior to returning your corrections.

Answer: Yes 


\section{elsevier_JCPS_526}

The author names have been tagged as given names and surnames (surnames are highlighted in teal color). Please confirm if they have been identified correctly.

Answer: Yes

Query:

Please check if the changes made here are OK.

Answer: OK

Query:

Uncited reference: This section comprises references that occur in the reference list but not in the body of the text. Please position each reference in the text or, alternatively, delete it. Thank you.

Answer: Please delete it.

Query:

Supplementary caption was not provided. Please check the suggested data if appropriate, and correct if necessary

Answer: No correction needed 